\title{
Chromosome Surveys in Penal Institutions and Approved Schools
}

\author{
PATRICIA A. JACOBS, WILLIAM H. PRICE, SHIRLEY RICHMOND, and \\ R. A. W. RATCLIFF \\ From the Medical Research Council, Clinical and Population Cytogenetics Unit, University Department of Medicine, \\ Western General Hospital, Edinburgh; and Scottish Home and Health Department
}

In 1965 it was shown that men with an additional $\mathrm{Y}$ chromosome were found in unusually large numbers in the Scottish State Hospital (Jacobs et al.), and this observation was substantiated by a similar finding in the English Special Hospitals (Casey et al., 1966) and among the inmates of comparable institutions in France (Noel et al., 1969). As the previous histories of more than half of the men with a 47,XYY constitution identified in the Scottish State Hospital had included periods of training in approved schools and borstal institutions and periods of imprisonment, it was decided to investigate the cytogenetic status of males in these establishments. The presence of an additional $\mathrm{Y}$ chromosome has been shown to be associated with increased stature (Jacobs et al., 1968) and because of this in a number of the populations which we studied we restricted the investigation to men who were $178 \mathrm{~cm}$. or more in height. (The present study was given further impetus by reports of the finding of $47, \mathrm{XYY}$ males in increased numbers among the tall inmates of prisons in England (Casey et al., 1966), Australia (Wiener et al., 1968), and the U.S.A. (Goodman and Smith, 1967), and among tall boys in an English approved school (Hunter, 1968)).

\section{Populations Studied}

The Scottish prisons, borstals, detention centre, and young offenders institutions (collectively known as the penal institutions) are administered by the Prison Division of the Scottish Home and Health Department in the name of the Secretary of State in accordance with the Prisons (Scotland) Act 1952. An approved school is 'a school approved by the Secretary of State for the education and training of children and young persons who are sent there by a Court'. The approved schools, unlike the penal institutions, are not managed by the Prison Division but by voluntary Boards of Managers or by local authorities.

Received 24 September 1970.

4-J.M.G.

\section{The penal institutions}

\section{(1) Prisons}

(a) Allocation centre-Saughton prison. In 1966 a new system of classification of prisons was introduced into Scotland and a national classification centre was set up in Saughton Prison, Edinburgh. Prisoners serving sentences of 12 months and more passed through this centre and on the basis of trade aptitudes or ability and willingness to participate in trade training programmes they were allocated to appropriate prisons. During the 12-month period, 1967-68, a survey of prisoners passing through this centre was carried out. In this period, 325 prisoners were admitted, of whom 302 men were examined, 20 refused to collaborate, and 3 were for other reasons unable to participate. The height and age distribution of these men is shown in Appendix I (Table A). During the time of study it is estimated that approximately one third of the prisoners committed to prison sentences of 12 months or more in Scotland were assessed at this centre.

(b) Tall Scottish prisoners. In the latter half of 1967 a second sample of Scottish prisoners was examined. These were men who were $178 \mathrm{~cm}$. or more in height from every prison in Scotland, and therefore included those serving short or long sentences, first offenders, or recidivists. After excluding those previously seen at the Allocation Centre, 453 men were listed and of these 24 would not co-operate and 10 were unavailable on the days that the prisons were visited. The distribution of heights and ages of the 419 men examined is shown in Appendix I (Table B).

\section{(2) Borstals, detention centre, young offenders institutions}

Borstals are designed to provide remedial and educational training as directed under the Criminal Justice (Scotland) Act 1949, Section 20, and 1963, Section 4, for not less than 16 but under 21 years of age who are convicted on indictment or summarily by Sheriff or stipendiary magistrate of offences punishable with imprisonment. It is required that the Court shall be satisfied that they will benefit from training and instruction conducive to their 'reformation and for the 
prevention of crime'. The length of stay is determined by the response to training and is on average about a year.

Detention centres are intended by Parliament to provide a sanction for those who could not be taught to respect the law by such milder measures as fines, probation, and attendance centres, but for whom long-term residential training is not necessary or desirable.

A young offender was, at the time of the Survey, defined as a person not less than 17 and not more than 21 years of age, who has been convicted of an offence punishable by imprisonment but who is considered unsuitable for borstal training or a sentence in a detention centre. Before the 1963 Act he would have been sentenced to imprisonment. Since the Act offenders in this agegroup are segregated from older prisoners, though if while serving their sentence they attain the age of 21 they are liable to complete their sentences in an ordinary adult prison.

(a) New borstal entrants. All borstal trainees in Scotland are admitted in the first instance for assessment of aptitudes and suitability for training programmes to a central borstal institution at Polmont. A chromosome survey was carried out at this borstal over a 12-month period from 1966-67 on 607 out of the 617 males who were admitted in that year (10 were not prepared to cooperate in the chromosome survey). The distribution by age and height of the 607 who were examined is shown in Appendix I (Table C).

(b) Tall males in detention centres. In Scotland there is only one detention centre, a senior establishment which at the time of the Survey was accepting youths who were 17 years of age but not yet 21 years (lower age limit is now 16 years), and for a fixed period of three months. The survey was restricted to males $178 \mathrm{~cm}$. or more in height and all 17 youths who were in this category were examined. Their height and age distribution is shown in Appendix I (Table D).

(c) Tall males in young offenders institutions. There are three young offenders institutions for males in Scotland and at the time of study they held 74 youths who were $178 \mathrm{~cm}$. or more in height. All were examined and their height and age distribution is shown in Appendix I (Table E).

\section{Approved schools}

Most of the children at approved schools have been committed by the Courts for offences against the criminal law while a small group are admitted under provisions of the Education (Scotland) Act 1962 for their persistent truancy. The remainder are children committed to the schools under the Children and Young Persons (Scotland) Act 1937 as being in need of care and protection usually because they are beyond parental control, exposed to moral danger, or falling into bad associations.

An approved school order is authority to detain in the school pupils who are 13 or under on committal for three years or until four months after they cease to be of school age, whichever is the later, and pupils who are 14 or over on committal for three years or until the age of 19 (in certain circumstances $19 \frac{1}{2}$ ), whichever is the earlier. In practice, however, very few pupils remain in the schools for the whole of this period of detention. The average length of time spent in the schools is under 18 months, release depending on the pupil's progress in the school, home circumstances, and age at committal.

In Scotland the age of criminal responsibility is 8 years (in England, since 1964, it has been 10 years), but the Scottish courts may not order a child under the age of 10 years to be sent to an approved school unless they are satisfied that he cannot suitably be dealt with otherwise.

Males in approved schools. During 1968, 16 of the Scottish approved schools were visited. The number of boys totalled 1,125, and of these 6 refused or were not available to take part in the study. Three other Scottish schools which together provide 154 places were unable to participate. The distribution by age and height of the 1119 boys examined is shown in Appendix I (Table F).

It will be clear from the above that the borstal, allocation centre, and approved school populations were unselected by heights, whereas the populations from the prisons, young offenders institutions, and detention centre were all of $178 \mathrm{~cm}$. or more. Moreoever the borstal and allocation centre populations represent the intake to these institutions over a clearly defined period, whereas the prisons, young offenders institutions, detention centre, and approved school populations represent the population in each institution on the particular day that it was visited. But since the prisons, young offenders institutions, and detention centre were all visited over a fairly short period (between July 1957 and February 1968) our samples probably reflect, reasonably accurately, the male population of $178 \mathrm{~cm}$. or more in Scottish penal institutions during the latter half of 1968. Similarly, the populations we studied from individual approved schools reflect the overall population in Scottish boys approved schools between March and October 1968.

\section{Methods}

All the institutions investigated except Polmont Borstal and Saughton Allocation Centre were visited on one occasion only, so it was necessary on occasions to be able to handle over 200 samples of blood at a time. An approximate idea of the number of individuals to be interviewed at each institution was obtained before each visit, and an appropriate number of $10 \mathrm{ml}$. sterile plastic tubes, each containing heparin and $4.5 \mathrm{ml}$. culture fluid $(4 \mathrm{ml}$. Ham's F10 tissue culture medium, $0.5 \mathrm{ml}$. bovine serum, $0.05 \mathrm{ml}$. Burroughs' Wellcome Phytohaemagglutinin, penicillin and streptomycin) was prepared together with a similar number of tubes containing heparin alone. A $5 \mathrm{ml}$. sample of venous blood was obtained from each individual who agreed to co-operate and $0.4 \mathrm{ml}$. inoculated into the tube containing the culture medium. The rest of the blood sample was added to the tube containing heparin. After transporting these samples back to the 
TABLE I

POPULATIONS STUDIED

\begin{tabular}{|c|c|c|c|c|c|}
\hline Population & $\begin{array}{l}\text { Total No. } \\
\text { of Males }\end{array}$ & $\begin{array}{l}\text { No. of Males } \\
\text { Who } \\
\text { Refused to } \\
\text { Co-operate } \\
\text { or Were } \\
\text { Unavailable } \\
\text { for Study }\end{array}$ & $\begin{array}{l}\text { Total No. } \\
\text { of Males } \\
\text { Examined }\end{array}$ & $\underset{(y r .)}{\text { Age Range }}$ & Height \\
\hline $\begin{array}{l}\text { Allocation Centre, Saughton } \\
\text { Prisons } \\
\text { Borstal New Entrants } \\
\text { Detention Centre } \\
\text { Young Offenders } \\
\text { Approved Schools }\end{array}$ & $\begin{array}{r}325 \\
453 \\
617 \\
17 \\
74 \\
1125\end{array}$ & $\begin{array}{r}23 \\
34 \\
10 \\
0 \\
0 \\
6\end{array}$ & $\begin{array}{r}302 \\
419 \\
607 \\
17 \\
74 \\
1119\end{array}$ & $\begin{array}{l}21+ \\
21+ \\
16-20 \\
17-20 \\
17-21 \\
8-18\end{array}$ & $\begin{array}{l}\text { Unselected } \\
\geqslant 178 \mathrm{~cm} . \\
\text { Unselected } \\
\geqslant 178 \mathrm{~cm} . \\
\geqslant 178 \mathrm{~cm} . \\
\text { Unselected }\end{array}$ \\
\hline Total & 2608 & 70 & 2538 & & \\
\hline
\end{tabular}

TABLE II

CHROMOSOME ABNORMALITIES FOUND IN PENAL INSTITUTIONS, WHERE POPULATION WAS UNSELECTED BY HEIGHT

\begin{tabular}{|c|c|c|c|c|}
\hline Case No. & Population & Abnormality & $\begin{array}{l}\text { Age } \\
\text { (yr.) }\end{array}$ & $\begin{array}{c}\text { Height } \\
\text { (cm.) }\end{array}$ \\
\hline $\begin{array}{r}76 / 66 \\
86 / 66 \\
102 / 66 \\
16 / 67 \\
82 / 66 \\
77 / 66 \\
243 / 67 \\
204 / 67\end{array}$ & $\begin{array}{l}\text { Borstal entrants } \\
\text { ", ", } \\
\text { ", ", } \\
\text { Allocation C̈entre, Saughton } \\
\text { ", ", }\end{array}$ & $\begin{array}{l}\text { 47,XYY } \\
\text { 47,XXY } \\
\text { 47,XXY } \\
\text { 46,XX } \\
\text { 46,XY,t(1 ? + ;Cq-) } \\
\text { 46,XY,inv(Cp- q +) } \\
\text { 45,XY,D -,D - ,t(DqDq) + } \\
\text { 45,XY,D -,G - ,t(DqGq) + }\end{array}$ & $\begin{array}{l}17 \\
17 \\
17 \\
19 \\
17 \\
19 \\
25 \\
31\end{array}$ & $\begin{array}{l}168 \\
157 \\
173 \\
173 \\
157 \\
171 \\
167 \\
175\end{array}$ \\
\hline
\end{tabular}

laboratory, the cultures were incubated for 2 to 3 days at $37 \mathrm{C}$., while the blood was stored at $4^{\circ} \mathrm{C}$., and was used to set up a second culture if the initial one did not give a satisfactory number of dividing cells. Chromosome preparations were made by the standard procedures.

In the survey of the new admissions to borstal, 10 cells were counted and analysed, but in all the other populations, two cells were counted and analysed from each individual. In every case at least one cell was checked by an independent observer. If both cells were entirely normal when two cells had been examined, or if 9 or 10 cells were entirely normal when 10 cells were examined, no further cells were analysed, but if any chromosome abnormality was seen or suspected a minimum of 30 cells was counted and analysed. Where an abnormality was found a second blood sample was obtained whereever possible, which in every instance confirmed the original observations.

\section{Results}

The total number of males in the various populations, the number who refused to co-operate or who were unavailable for study, and the actual number examined are shown in Table I, together with the age and height range of each population.

A satisfactory culture was obtained from all the 2538 males studied, and of these, 25 were found to have an abnormal karyotype. Details of the
TABLE III

CHROMOSOME ABNORMALITIES FOUND IN PENAL INSTITUTIONS, WHERE POPULATION WAS RESTRICTED BY HEIGHT

\begin{tabular}{|c|c|c|c|c|}
\hline $\begin{array}{l}\text { Case } \\
\text { No. }\end{array}$ & Population & Abnormality & Age & $\begin{array}{l}\text { Height } \\
(\mathrm{cm} .)\end{array}$ \\
\hline $\begin{array}{l}342 / 67 \\
341 / 67\end{array}$ & $\begin{array}{l}\text { Prison } \\
\text { Young } \\
\text { Offenders } \\
\text { Institution }\end{array}$ & $\begin{array}{l}\text { 47,XYY } \\
47, X Y Y\end{array}$ & $\begin{array}{l}38 \\
17\end{array}$ & $\begin{array}{l}190 \\
198\end{array}$ \\
\hline $\begin{array}{l}358 / 67 \\
343 / 67 \\
352 / 67 \\
344 / 67\end{array}$ & $\begin{array}{l}\text { Prison } \\
\text { Prison } \\
\text { Prison } \\
\text { Prison }\end{array}$ & $\begin{array}{l}\text { 47,XXY } \\
\text { 47,XXY } \\
\text { 46,XY,t(1 ? - ;16p +) } \\
47, X Y, \text { mar + }\end{array}$ & $\begin{array}{l}44 \\
35 \\
32 \\
24\end{array}$ & $\begin{array}{l}179 \\
185 \\
183 \\
180\end{array}$ \\
\hline
\end{tabular}

TABLE IV

CHROMOSOME ABNORMALITIES FOUND IN SCOTTISH APPROVED SCHOOLS

\begin{tabular}{|c|c|c|c|}
\hline Reg. No. & Abnormality & $\begin{array}{l}\text { Age } \\
\text { (yr.) }\end{array}$ & $\begin{array}{c}\text { Height } \\
\text { (cm.) }\end{array}$ \\
\hline $\begin{array}{l}132 / 68 \\
209 / 68 \\
120 / 68 \\
156 / 68 \\
229 / 68 \\
228 / 68 \\
102 / 68 \\
\text { K53/211/68 } \\
\text { K54/245/68 } \\
\text { K57/210/68 } \\
157 / 68\end{array}$ & 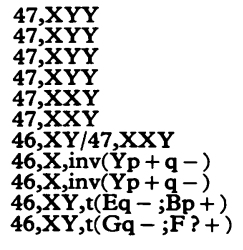 & $\begin{array}{l}8 \frac{1}{2} \\
13 \frac{1}{2} \\
14 \frac{1}{2} \\
15 \frac{1}{2} \\
13 \\
14 \\
15 \frac{1}{2} \\
14 \frac{1}{\frac{1}{2}} \\
14 \frac{1}{2} \\
10 \\
16\end{array}$ & $\begin{array}{l}127 \\
171 \\
168 \\
173 \\
143 \\
154 \\
170 \\
157 \\
160 \\
131 \\
179\end{array}$ \\
\hline
\end{tabular}


chromosome abnormalities together with the heights and ages of the individuals, and the type of institution in which they were identified are shown in Tables II-IV. Cytogenetic data and further details of these individuals are given in Appendix II.

\section{Discussion}

47,XYY males. Surveys carried out on babies shortly after birth show that $47, \mathrm{XYY}$ males occur in the newborn population with a frequency of about 1 in 700 (Ratcliffe et al., 1970). As there is no evidence at present to suggest that individuals with this karyotype have an increased mortality risk by comparison with $46, \mathrm{XY}$ males, it is reasonable to assume that their frequency in the adult general population is of the same order. The findings described in this paper therefore do not suggest that there is any significant difference between the frequency with which $47, \mathrm{XYY}$ males occur in penal and related institutions in Scotland by comparison with their frequency in the general population. Thus, among the 909 males, not selected on the basis of height, who were examined in penal institutions only one was found to have a $47, \mathrm{XYY}$ chromosome constitution, while 4 of the 1119 boys examined in approved schools were found to have a $47, \mathrm{XYY}$ constitution, an incidence not significantly different from that in the newborn.

Among the 510 men from penal institutions who were $178 \mathrm{~cm}$. or more in height, only 2 were found to have a $47, \mathrm{XYY}$ constitution. If it is assumed that approximately $25 \%$ of the adult male population are $178 \mathrm{~cm}$. or more in height (Tanner, Whitehouse, and Takaishi, 1966) and that approximately $75 \%$ of adult $47, X Y Y$ are $178 \mathrm{~cm}$. or more in height (Court Brown, 1968), approximately 1 in 210 of the adult male population who are of this height would be expected to have a 47,XYY constitution. Therefore the finding of 2 in a population of 510 is clearly no more than would be expected by chance.

We know that $47, \mathrm{XYY}$ men have an increased risk of being patients in the Scottish State Hospital which provides specifically for the patient offender who, because of dangerous, violent, or criminal propensities, requires detention under conditions of maximum security. Furthermore over half the $47, \mathrm{XYY}$ 's identified in this institution had previously been in prison or approved school or penal institution for corrective training. However this may represent an accumulation of such men over many years (Price and Whatmore, 1967), but, because of our incomplete knowledge of the 47,XYY male and of the admission and discharge policy during that time, the reasons for the failure to find an increased incidence of such men in the populations reported in the present study can only be speculative.

The findings described in this paper suggest that in Scotland the increased risk of criminal behaviour in the $47, \mathrm{XYY}$ male is confined to those that are mentally disordered and liable to be admitted as patient offenders to the State Hospital. The male population of Scotland aged 15 years or more is approximately 1.8 million, and if the incidence of $47, \mathrm{XYY}$ males is the same as that in the newborn there are approximately 2,500 men with this karyotype. The 9 men at the State Hospital represent $0.36 \%$ of this total, whereas the total State Hospital population represents $0.02 \%$ of the general adult male population-a twentyfold increase in risk for the $47, X Y Y$ male.

There is at present no information on the risk of mental disorder in non-offenders with this karyotype. Of the 7 males with a $47, \mathrm{XYY}$ karyotype identified during the course of the present surveys, one is mentally handicapped and another 3 are considered by psychiatrists to be mentally abnormal. The remaining 2 on whom clinical data are available are not suspected to be suffering from any mental disorder. The social environment of the majority of these $47, \mathrm{XYY}$ males might reasonably be considered conducive to behaviour disorders and lead to their admission to these institutions. This is in contrast to the findings at the State Hospital where there was reason for attributing a psychopathic personality to a constitutional disorder such as a chromosome abnormality (Price and Whatmore, 1967).

Males with a $47, \mathrm{XYY}$ constitution have been reported, in increasing numbers, in penal and corrective training establishments in other countries. The present apparent difference from this experience, if it is confirmed, may be accounted for by differences in the legal system in different countries. There may also be variation in the provision of facilities for treatment of the mentally disordered offender in different countries. For example the number of beds per head of the population provided in the State or Special Hospitals for patient offenders is $50 \%$ greater in Scotland than in England.

Other chromosome abnormalities. In the total population of 2538 males examined, 5 were found to have a 47,XXY chromosome constitution. This is not significantly different from the incidence in the newborn population which is about 1 in 700 . This comparison does not take into consideration the fact that 510 of the men examined were selected on the basis of increased stature, and it is known that $47, \mathrm{XXY}$ men are taller on average 
than the general population. For this reason alone we might well have expected to find more in the institutions selected in this way than in the newborn, but there was no significant difference. In addition one male was found to have an apparently normal female chromosome complement and one was found to be a $46, \mathrm{XY} / 47, \mathrm{XXY}$ mosaic, the great majority of his cells having a 46,XY constitution. A further two boys were found to have a metacentric Y chromosome, presumed to be the result of a pericentric inversion, and in both cases it was found to be familial and present in all the male relatives who were studied. These surveys provide no evidence of an association between these chromosome abnormalities and criminal behaviour.

Seven individuals were found to have a structural rearrangement of the autosomes: in 4 cases this was a reciprocal translocation, in 2 cases a Robertsonian translocation, and in 1 a pericentric inversion of a medium-sized chromosome. It has been possible to study the families of 6 of these individuals and in every case the abnormality has been found to be familial. The last remaining abnormality was a man with 47 chromosomes who was found to have an additional small metacentric chromosome which was less than half the size of the G group autosomes. It has not yet been possible to study any of his relatives, and from the appearance of the chromosomes it is not possible to say whether or not it represents additional sex chromosome material or additional autosome material. From the data published on surveys of the newborn the incidence of apparently balanced autosome structural rearrangements of the autosomes appears to be of the order of 1 in 600 which is not significantly different $(p>0 \cdot 2)$ from the incidence of these abnormalities found in the present surveys.

\section{Summary}

The chromosomes of 2538 males from a variety of penal and corrective institutions have been examined. There was no significant difference found between the incidence of males with an abnormality of the sex chromosomes, in particular with a $47, \mathrm{XYY}$ complement, in these establishments and the incidence of such males among the newborn. There was also no significant difference in the number of males with an autosome structural rearrangement.

We are grateful to the Directors of the Scottish Prison Service, Dr. H. B. Craigie and Dr. J. Ward, of the Scottish Home and Health Department; to the Governors of the Penal Institutions; and to the Managers and the Headmasters of the Approved Schools without whose help the present investigation would have been impossible. We would also like to thank all those members of staff of the Medical Research Council's Clinical and Population Cytogenetics Unit who contributed to the study.

\section{REFERENCES}

Casey, M. D., Blank, C. E., Street, D. R. K., Segall, L. J., McDougall, J. H., McGrath, P. J., and Skinner, J. L. (1966). YY chromosomes and antisocial behaviour. Lancet, 2, 859-860.

Court Brown, W. M. (1968). Males with an XYY sex chromosome complement. Fournal of Medical Genetics, 5, 341-359.

Goodman, R. M. and Smith, W. S. (1967). Sex chromosome abnormalities. Nature (London), 216, 942-943.

Hunter, H. (1968). Chromatin-positive and XYY boys in approved Schools. Lancet, 1, 816.

Jacobs, P. A., Brunton, M., Melville, M. M., Brittain, R. P., and McClemont, W. F. (1965). Aggressive behaviour, mental subnormality and the XYY male. Nature (London), 208, 1351-1352. - Price, W. H., Court Brown, W. M., Brittain, R. P., and Whatmore, P. B. (1968). Chromosome studies on men in a maximum security hospital. Annals of Human Genetics, 31, 339-358.

Noel, B., Quack, B., Durand, Y., and Rethoré, M. O. (1969). Les hommes 47,XYY. Annales de Génétique, 12, 223-236.

Price, W. H. and Whatmore, P. B. (1967). Behaviour disorders and Pattern of crime among XYY males identified at a maximum security hospital. British Medical fournal, 1, 533-536.

Ratcliffe, S. G., Stewart, A. L., Melville, M. M., Jacobs, P. A., and Keay, A. J. (1970). Chromosome studies on 3,500 newborn male Infants. Lancet, 1, 121-122.

Tanner, J. M., Whitehouse, R. H., and Takaishi, M. (1966). Standards from birth to maturity for height, weight, height velocity and weight velocity: British children, 1965. Archives of Disease in Childhood, 41, 454-471 and 613-635.

Wiener, S., Sutherland, G., Bartholomew, A. A., and Hudson, B. (1968). XYY males in a Melbourne prison. Lancet, 1, 150 
APPENDIX I

TABLE A

HEIGHTS AND AGES OF MALES EXAMINED AT ALLOCATION CENTRE, SAUGHTON PRISON, EDINBURGH

\begin{tabular}{|c|c|c|c|c|c|c|c|c|c|c|c|}
\hline \multirow{2}{*}{ Age (yr.) } & \multicolumn{11}{|c|}{ Height (cm.) } \\
\hline & $150-$ & $155-$ & $160-$ & $165-$ & $170-$ & $175-$ & $178-$ & $183-$ & $185 \cdot 5-$ & $188+$ & All Heights \\
\hline $\begin{array}{l}15- \\
20- \\
25- \\
30- \\
35- \\
40- \\
45- \\
50- \\
55- \\
60- \\
65-\end{array}$ & $\begin{array}{l}0 \\
0 \\
0 \\
0 \\
0 \\
0 \\
0 \\
0 \\
0 \\
0 \\
0\end{array}$ & $\begin{array}{l}0 \\
2 \\
1 \\
1 \\
0 \\
2 \\
1 \\
1 \\
0 \\
1 \\
0\end{array}$ & $\begin{array}{r}0 \\
5 \\
10 \\
8 \\
5 \\
5 \\
2 \\
2 \\
0 \\
0 \\
0\end{array}$ & $\begin{array}{r}0 \\
25 \\
11 \\
12 \\
9 \\
8 \\
1 \\
4 \\
0 \\
1 \\
1\end{array}$ & $\begin{array}{r}0 \\
33 \\
28 \\
13 \\
10 \\
5 \\
4 \\
1 \\
0 \\
0 \\
0\end{array}$ & $\begin{array}{r}0 \\
15 \\
8 \\
4 \\
1 \\
3 \\
1 \\
0 \\
0 \\
0 \\
0\end{array}$ & $\begin{array}{r}0 \\
20 \\
10 \\
8 \\
3 \\
5 \\
0 \\
0 \\
0 \\
0 \\
0\end{array}$ & $\begin{array}{l}0 \\
1 \\
2 \\
0 \\
1 \\
0 \\
0 \\
0 \\
0 \\
0 \\
0\end{array}$ & $\begin{array}{l}0 \\
3 \\
1 \\
0 \\
0 \\
0 \\
0 \\
0 \\
0 \\
0 \\
0\end{array}$ & $\begin{array}{l}0 \\
0 \\
0 \\
1 \\
1 \\
0 \\
1 \\
0 \\
0 \\
1 \\
0\end{array}$ & $\begin{array}{r}0 \\
104 \\
71 \\
47 \\
30 \\
28 \\
10 \\
8 \\
0 \\
3 \\
1\end{array}$ \\
\hline All ages & 0 & 9 & 37 & 72 & 94 & 32 & 46 & 4 & 4 & 4 & 302 \\
\hline
\end{tabular}

TABLE B

HEIGHTS AND AGES OF MALES EXAMINED IN SCOTTISH PRISONS

\begin{tabular}{|c|c|c|c|c|c|c|c|c|c|c|c|}
\hline \multirow{2}{*}{ Age (yr.) } & \multicolumn{11}{|c|}{ Height (cm.) } \\
\hline & $150-$ & $155-$ & $160-$ & $165-$ & $170-$ & $175-$ & $178-$ & $183-$ & $185 \cdot 5-$ & $188+$ & All Heights \\
\hline $\begin{array}{l}15- \\
20- \\
25- \\
30- \\
35- \\
40- \\
45- \\
50- \\
55- \\
60- \\
65+\end{array}$ & $\begin{array}{l}0 \\
0 \\
0 \\
0 \\
0 \\
0 \\
0 \\
0 \\
0 \\
0 \\
0\end{array}$ & $\begin{array}{l}0 \\
0 \\
0 \\
0 \\
0 \\
0 \\
0 \\
0 \\
0 \\
0 \\
0\end{array}$ & $\begin{array}{l}0 \\
0 \\
0 \\
0 \\
0 \\
0 \\
0 \\
0 \\
0 \\
0 \\
0\end{array}$ & $\begin{array}{l}0 \\
0 \\
0 \\
0 \\
0 \\
0 \\
0 \\
0 \\
0 \\
0 \\
0\end{array}$ & $\begin{array}{l}0 \\
0 \\
0 \\
0 \\
0 \\
0 \\
0 \\
0 \\
0 \\
0 \\
0\end{array}$ & $\begin{array}{l}0 \\
0 \\
0 \\
0 \\
0 \\
0 \\
0 \\
0 \\
0 \\
0 \\
0\end{array}$ & $\begin{array}{r}1 \\
72 \\
79 \\
50 \\
30 \\
28 \\
19 \\
5 \\
6 \\
2 \\
1\end{array}$ & $\begin{array}{r}0 \\
20 \\
15 \\
15 \\
11 \\
7 \\
3 \\
3 \\
1 \\
0 \\
0\end{array}$ & $\begin{array}{r}0 \\
15 \\
12 \\
1 \\
2 \\
1 \\
0 \\
0 \\
0 \\
0 \\
0\end{array}$ & $\begin{array}{l}0 \\
7 \\
5 \\
3 \\
1 \\
2 \\
2 \\
0 \\
0 \\
0 \\
0\end{array}$ & $\begin{array}{r}1 \\
114 \\
111 \\
69 \\
44 \\
38 \\
24 \\
8 \\
7 \\
2 \\
1\end{array}$ \\
\hline All ages & 0 & 0 & 0 & 0 & 0 & 0 & 293 & 75 & 31 & 20 & 419 \\
\hline
\end{tabular}

TABLE C

HEIGHTS AND AGES OF NEW BORSTAL ENTRANTS

\begin{tabular}{|c|c|c|c|c|c|c|c|c|c|c|c|}
\hline \multirow{2}{*}{ Age (yr.) } & \multicolumn{11}{|c|}{ Height (cm.) } \\
\hline & $150-$ & $155-$ & $160-$ & $165-$ & $170-$ & $175-$ & $178-$ & $183-$ & $185 \cdot 5-$ & $188+$ & All Heights \\
\hline $\begin{array}{c}15-19 \\
20+\end{array}$ & $\begin{array}{l}8 \\
0\end{array}$ & $\begin{array}{r}20 \\
1\end{array}$ & $\begin{array}{r}119 \\
6\end{array}$ & $\begin{array}{r}163 \\
12\end{array}$ & $\begin{array}{r}152 \\
12\end{array}$ & $\begin{array}{r}48 \\
6\end{array}$ & $\begin{array}{r}42 \\
4\end{array}$ & $\begin{array}{l}9 \\
1\end{array}$ & $\begin{array}{l}3 \\
0\end{array}$ & $\begin{array}{l}1 \\
0\end{array}$ & $\begin{array}{r}565 \\
42\end{array}$ \\
\hline All ages & 8 & 21 & 125 & 175 & 164 & 54 & 46 & 10 & 3 & 1 & 607 \\
\hline
\end{tabular}

TABLE D

THE HEIGHTS AND AGES OF MALES EXAMINED AT DETENTION CENTRE

\begin{tabular}{c|c|c|c|c|c|c|c|c|c|c|c}
\hline \multirow{2}{*}{ Age (yr.) } & \multicolumn{10}{c}{ Height (cm.) } \\
\cline { 2 - 10 } & $150-$ & $155-$ & $160-$ & $165-$ & $170-$ & $175-$ & $187-$ & $183-$ & $185 \cdot 5-$ & $188+$ & All Heights \\
\hline $15-$ & 0 & 0 & 0 & 0 & 0 & 0 & 12 & 3 & 0 & 1 & 16 \\
$20+$ & 0 & 0 & 0 & 0 & 0 & 0 & 1 & 0 & 0 & 0 & 1 \\
\hline All ages & 0 & 0 & 0 & 0 & 0 & 0 & 13 & 3 & 0 & 1 & 17 \\
\hline
\end{tabular}


TABLE E

HEIGHTS AND AGES OF MALES EXAMINED AT SCOTTISH YOUNG OFFENDERS INSTITUTIONS

\begin{tabular}{c|c|c|c|c|c|c|c|c|c|c|c}
\hline & \multicolumn{1}{c}{ Height (cm.) } \\
\cline { 2 - 7 } & $150-$ & $155-$ & $160-$ & $165-$ & $170-$ & $175-$ & $178-$ & $183-$ & $185 \cdot 5-$ & $188+$ & All Heights \\
\hline $15-$ & 0 & 0 & 0 & 0 & 0 & 0 & 32 & 4 & 3 & 1 & 40 \\
$20+$ & 0 & 0 & 0 & 0 & 0 & 0 & 26 & 2 & 5 & 1 & 34 \\
\hline All ages & 0 & 0 & 0 & 0 & 0 & 0 & 58 & 6 & 8 & 2 & 74 \\
\hline
\end{tabular}

TABLE F

HEIGHTS AND AGES OF MALES EXAMINED IN SCOTTISH APPROVED SCHOOLS

\begin{tabular}{|c|c|c|c|c|c|c|c|c|c|c|c|c|c|c|c|c|}
\hline \multirow{2}{*}{ Age (yr.) } & \multicolumn{15}{|c|}{ Height $(\mathrm{cm})}$. & \multirow{2}{*}{ All Heights } \\
\hline & $115-$ & $120-$ & $|125-|$ & $\mid 130-$ & $135-$ & $140-$ & $145-$ & $150-$ & $155-$ & $160-$ & $165-$ & | $170-$ & $175-$ & $178-$ & $183+$ & \\
\hline $\begin{array}{r}8- \\
9- \\
10- \\
11- \\
12- \\
13- \\
14- \\
15- \\
16- \\
17- \\
18+\end{array}$ & $\begin{array}{l}= \\
= \\
= \\
= \\
=\end{array}$ & $\begin{array}{l}1 \\
\frac{1}{3} \\
= \\
= \\
= \\
=\end{array}$ & $\begin{array}{l}1 \\
4 \\
6 \\
7 \\
1 \\
= \\
= \\
=\end{array}$ & $\begin{array}{r}5 \\
17 \\
13 \\
10 \\
4 \\
= \\
= \\
=\end{array}$ & $\begin{array}{r}4 \\
9 \\
28 \\
33 \\
10 \\
5 \\
1 \\
=\end{array}$ & $\begin{array}{l}= \\
6 \\
24 \\
35 \\
31 \\
12 \\
1 \\
= \\
=\end{array}$ & $\begin{array}{l}= \\
\overline{7} \\
29 \\
41 \\
47 \\
13 \\
1 \\
=\end{array}$ & $\begin{array}{r}= \\
11 \\
1 \\
8 \\
42 \\
57 \\
14 \\
5 \\
=\end{array}$ & $\begin{array}{r}= \\
\bar{z} \\
5 \\
35 \\
61 \\
23 \\
10 \\
6 \\
-\end{array}$ & $\begin{array}{l}= \\
= \\
1 \\
20 \\
47 \\
69 \\
22 \\
-7\end{array}$ & $\begin{array}{r}= \\
= \\
\overline{7} \\
5 \\
36 \\
36 \\
27 \\
19 \\
1\end{array}$ & $\begin{array}{r}\bar{Z} \\
\bar{Z} \\
\overline{4} \\
17 \\
32 \\
31 \\
12 \\
4\end{array}$ & $\begin{array}{l}\bar{Z} \\
\bar{Z} \\
\overline{1} \\
1 \\
2 \\
9 \\
7 \\
5 \\
2\end{array}$ & $\begin{array}{l}= \\
\bar{Z} \\
\overline{7} \\
1 \\
3 \\
5 \\
5 \\
4 \\
1\end{array}$ & $\begin{array}{l}= \\
= \\
= \\
\overline{1} \\
\frac{1}{1}\end{array}$ & $\begin{array}{r}2 \\
17 \\
42 \\
80 \\
122 \\
195 \\
287 \\
203 \\
109 \\
54 \\
8\end{array}$ \\
\hline All ages & 3 & 6 & 19 & 49 & 90 & 109 & 138 & 128 & 140 & 166 & 124 & 100 & 26 & 19 & 2 & 1119 \\
\hline
\end{tabular}

\section{APPENDIX II}

\section{Details of Individuals with Abnormal Chromosome Constitution}

\section{Individuals identified in survey of tall prisoners}

Case 341/67. 47,XYY. Aged 17. Occupationnone. Attended a school for the mentally handicapped. No data available on childhood development and social background. Previously convicted for stealing food and confectionery and for shoplifting; fined and placed on probation. Identified while serving a sentence of imprisonment for theft of a motor car. Slight bilateral gynaecomastia. Varicose veins in both legs. Otherwise normal physical and sexual development.

Case 342/67. 47,XYY. Aged 38 when identified. Occupation-ganger. No data on childhood and early adult life. Bigamously married, convicted of this in 1960. The registered father of a boy born in 1957 by this bigamous marriage. Only other recorded offence is malicious mischief for which he was serving a sentence of 30 days imprisonment when he was identified. Killed one year later in a building site accident. No clinical data available.

Case 343/67. 47,XXY. Aged 35. Occupationelectrician. No data available on early childhood. Charged with theft at age of 10 years and again at age 14 years, on both occasions placed on probation. At age 15 years appeared in court on four charges of theft by housebreaking, sentenced to borstal training. Not convicted of further offences until 1959 when he was fined for offence of theft by housebreaking. Identified while serving another prison sentence for theft. Average intelligence. Testes less than $1.5 \mathrm{~cm}$. long. Only slight facial hair growth, otherwise normal physical and sexual development.

Case 358/67. 47,XXY. Aged 44. No data available on early development and childhood social background. Long history of serious physical and mental ill health including rheumatic heart disease, peptic ulceration, and paranoid schizophrenia. Mitral valvulotomy in 1954, partial gastrectomy in 1961. Pulmonary infarct following deep venous thrombosis of the left leg, 1964. Epileptic and high grade mental handicap. He claims his family disown him and that he is compelled to steal as he is unable to obtain suitable employment. First convicted at age 14 years for theft-admitted to an approved school. Absconded and was transferred for borstal training; three years later convicted again of theft and sentenced to a second period of borstal training. Subsequently 32 convictions for theft; several periods of imprisonment of up to four years' duration. Since he was identified in the chromosome survey he has been transferred to a maximum security hospital. Both testes small, less than $1.5 \mathrm{~cm}$. in length; otherwise normal sexual development. Signs of mixed mitral and aortic valve disease. Evidence of venous insufficiency in the left leg. 
Case 344/67. 47,XY,mar +. Aged 24. Occupation - plumber. No data on family or social background. Committed to an approved school when a child, later sentenced to borstal training. Subsequently had several prison sentences usually, as on the present occasion, for assault. Attributes his violent behaviour to the effects of alcohol but has been known to assault a fellow prisoner and a prison officer while serving a prison sentence and not under the influence of alcohol. Average intelligence. Normal physical development.

Case 352/67. 46,XY,t(1 ? - ;16p+). Aged 32. Occupation-barman. No data on childhood social background. Previously sentenced to borstal training and to several periods of inprisonment for a total of 28 charges of fraud. Identified when serving a sentence of imprisonment for theft and attempted fraud. Previously suffered from ruptured ureter and osteomyelitis of leg, both as a result of injury. Married for eight years and infertile. Believes he has had a child by another woman. Average intelligence. Normal physical development.

\section{Individuals identified in survey of Saughton Allo- cation Centre}

Case 243/67. 45,XY,D-,D-,t(DqGq)+. Aged 26. No data on social circumstances in childhood and adolescence. Married, 1 child. Previously convicted for minor offences at age 15 years and again at age 22 years. Identified while serving a life sentence for murder committed at the age of 25 . Average intelligence. No abnormality of physical development.

Case 204/67. 45,XY,D-,G-,t(DqGq) +. Aged 31 . Parents separated when propositus aged 8 . Not married but has one child. Several convictions for theft from the age of 24 years. Average intelligence. Normal physical development.

\section{Individuals identified in survey of Polmont Borstal}

Case 76/66. 47,XYY. Aged 17. Occupation-apprentice waiter. Mother of the propositus died when he was 2 years of age, at which time the father deserted the family. The propositus was adopted by a maternal aunt and her husband but the adoptive mother died when the propositus was 13 years of age. Convicted of breaking and entering with theft in 1963. Sent to approved school. Further conviction for attempting to break and enter in 1964-admonished. Convicted of malicious damage and theft in 1966. Sent for borstal training. Homosexual. IQ (Terman Merrill) 90. Bilateral genu-varum. Physical and sexual development otherwise normal.

Case 102/66. 47,XXY. Aged 17. Occupationroad sweeper. According to the mother his behaviour had been satisfactory until he associated with a delinquent youth. No data available from his school. Sentenced to borstal training for stealing a motor bike. Previously placed on probation for housebreaking and theft of money. Low average intelligence. Scanty facial hair. Both testes less than $1 \mathrm{~cm}$. long. Otherwise normal physical and sexual development.

Case 86/66. 47,XXY. Aged 17. Occupation-van boy. No data available on childhood development or social background. Several convictions for breaking and entering with theft and previously committed to approved school. Sentenced to borstal training in 1966 for similar offence. Average intelligence. Testes less than $1 \mathrm{~cm}$. long. No facial hair growth and slight gynaecomastia. Otherwise normal physical development.

Case 16/67. 46,XX. Aged 20. Occupation-apprentice chef. No data on social background. Convicted of theft and sent to an approved school at age 13. Placed on probation for theft of a car and six other offences at 17 years. Sentenced to borstal training for theft of a car. Shortly before this attempted suicide after quarrelling with a girl friend. Low average intelligence. Both testes small; less than $1.5 \mathrm{~cm}$. in length. Only slight facial hair growth. Otherwise normal physical and sexual development.

Case 82/66. 46,XY,t(1 ?+; $\mathrm{Cq}-)$. Aged 16. No family or social data available. Previously committed to an approved school for theft and assault. Sentenced to borstal training for theft. Average intelligence. No abnormality of physical development.

Case 77/66. 46,XY, $\operatorname{inv}(\mathrm{Cp}-\mathrm{q}+)$. Aged 21. Said to have a long history of delinquent behaviour. Details not available. Sentenced to borstal training for robbery with violence. Average intelligence. No abnormality of physical development.

\section{Individuals identified in survey of approved schools}

Case 132/68. 47,XYY. Aged 9. Parents divorced. A regular truant from school. Apprehended for two acts of fire raising. Reprimanded for petty thefts and assault on a much younger child before being sent to approved school for malicious mischief. Shy with adults, solitary and immature but enjoys attention and friendship. Careless, stubborn and sulky when reprimanded. Emotionally disturbed, overdependent and infantile. IQ (WISC age 8) verbal 87, performance 95, full scale 90. Testes in inguinal canals but could be brought into the scrotum. Physical development otherwise normal.

Case 209/68. 47,XYY. Aged 14. Familial background of antisocial behaviour and petty crime. Unreliable; frequent truant; court appearances for malicious mischief, repeated theft, and theft with assault on a smaller boy. At approved school seeks attention, provokes other boys, and lacks perseverance. Not noted to be violent but has often been the victim of violence himself. IQ (Moray House verbal reasoning test) 70 . Physical and sexual development consistent with his age.

Case 120/68. 47,XYY. Aged 15. Brought up by mother until age 7 , then placed in an institution; fostered at age of 9 years, adopted age 10 . Became destruc- 
tive, aggressive, and dishonest, and described as living in a fantasy world. Difficulty in forming relationships. Occasional cruelty towards younger children. Convicted of making false telephone calls at age 12 years. Sent to an approved school, noted to show a slight fear of the dark, boasted about minor acts of delinquency, touchy and moody. Showed no signs of destructiveness, aggressiveness, dishonesty, or sexual misbehaviour. Not considered a delinquent. Discharged to a local authority Children's Home at age 13 years. Readmitted after appearing in court on charges of theft and house breaking. IQ (WISC age 12) full scale 79, verbal scale 92 , performance scale 68 . No detectable physical abnormalities. Sexual development consistent with age.

Case 156/68. 47,XYY. Aged 16. Family background of physical and mental illness, including a suicide. A skilful truant. Quiet, withdrawn, and completely uninterested in school activities. Reported by psychiatrist to be seriously disturbed. Nocturnal enuretic. Said to faint easily. Sent to approved school for theft by housebreaking Average intelligence. Normal physical development.

Case 229/68. 47,XXY. Aged 13. Parents separated. Frequent truant from school. Sent to approved school for theft by housebreaking (two charges). IQ (Terman Merrill, 1968) 78. Testes not palpable. Right inguinal hernia. Physical and sexual development otherwise normal.

Case 228/68. 47,XXY. Aged 14. Convicted of wilful fire raising at age 9 years, of housebreaking and malicious mischief at age 11 years. Admitted to apapproved school for malicious mischief. No data on family background. IQ (Terman Merrill) 59. Both testes small, $2 \mathrm{~cm} . \times 0.75 \mathrm{~cm}$. Physical and sexual development otherwise normal.

Case 102/68. 46,XY/47,XXY. Aged 16. Regular truant from school. By age 15 years had been in court on several occasions for theft. Sent to approved school for stealing. Average intelligence. Physical development normal. Testes normal.

Case 211/68. 46,X,inv(Yp+;q-). Aged 14. Family background of petty theft and violence. History of truancy from school. Convicted of theft by shoplifting at age 12 years, by housebreaking at age 13 and again at age 14 when he was committed to approved school. Again found guilty of housebreaking when allowed home on leave. IQ (WISC) 99. Normal physical development.

Case 245/68. 46,X,inv(Yp+;q-). Aged 14. No family or social data. Committed to approved school for petty thieving. Average intelligence. Normal physical development.

Case 210/68. 46,XY,t(Bp + ;Eq-). Aged 10 . Parents separated when boy aged 3 years and for a time cared for in a children's home from which he absconded several times. Sent to an approved school for theft by housebreaking. Enuretic. Low average intelligence. Normal physical development.

Case 157/68. 46,XY,t(F ? + ;Gq-). Aged 16. No data on family background. Convicted of theft at age 10,14 , and again at 15 when committed to an approved school. Average intelligence. Normal physical development.

TABLE a

FAMILY DATA ON INDIVIDUALS WITH ABNORMAL CHROMOSOME CONSTITUTION

\begin{tabular}{|c|c|c|c|c|c|c|c|}
\hline $\begin{array}{l}\text { Case } \\
\text { No. }\end{array}$ & $\begin{array}{l}\text { Chromosome } \\
\text { Constitution }\end{array}$ & $\begin{array}{l}\text { Age } \\
(y r .)\end{array}$ & $\begin{array}{l}\text { Maternal Age } \\
\text { at Birth }\end{array}$ & $\begin{array}{l}\text { Paternal Age } \\
\text { at Birth }\end{array}$ & $\underset{\text { Size }}{\text { Sibship }}$ & $\begin{array}{l}\text { Birth } \\
\text { Rank }\end{array}$ & Comments \\
\hline $\begin{array}{r}132 / 68 \\
209 / 68 \\
120 / 68 \\
156 / 68 \\
341 / 67 \\
76 / 66 \\
342 / 67 \\
229 / 68 \\
228 / 68 \\
102 / 66 \\
86 / 66\end{array}$ & $\begin{array}{l}47, X Y Y \\
47, X Y Y \\
47, X Y Y \\
47, X Y Y \\
47, X Y Y \\
47, X Y Y \\
47, X Y Y \\
47, X X Y \\
47, X X Y \\
47, X X Y \\
47, X X Y\end{array}$ & $\begin{array}{l}9 \\
14 \\
15 \\
16 \\
17 \\
17 \\
38 \\
13 \\
14 \\
17 \\
17\end{array}$ & $\begin{array}{l}18 \\
27 \\
27 \\
25 \\
32 \\
30 \\
28 \\
35 \\
31 \\
29 \\
35\end{array}$ & $\begin{array}{c}21 \\
31 \\
\text { No data } \\
26 \\
33 \\
30 \\
30 \\
35 \\
31 \\
33 \\
30\end{array}$ & $\begin{array}{r}2 \\
4 \\
1 \\
6 \\
2 \\
3 \\
5 \\
6 \\
13 \\
2 \\
10\end{array}$ & $\begin{array}{l}1 \\
3 \\
1 \\
3 \\
2 \\
2 \\
1 \\
5 \\
8 \\
2 \\
7\end{array}$ & \multirow{5}{*}{$\begin{array}{l}\text { Sibs } 1-6 \text { are maternal } \\
\text { half sibs } \\
\text { Sibs } 1-2 \text { are paternal } \\
\text { half sibs } \\
\text { Sibs } 1-4 \text { are maternal } \\
\text { half sibs } \\
\text { Sibs } 5-6 \text { are maternal } \\
\text { half sibs }\end{array}$} \\
\hline $\begin{array}{r}343 / 67 \\
358 / 67 \\
102 / 68 \\
16 / 67\end{array}$ & $\begin{array}{l}47, X X Y \\
47, X X Y \\
46, X Y / 47, X X Y \\
46, X X\end{array}$ & $\begin{array}{l}35 \\
44 \\
16 \\
20\end{array}$ & $\begin{array}{l}27 \\
42 \\
23 \\
37\end{array}$ & $\begin{array}{l}22 \\
41 \\
24 \\
44\end{array}$ & $\begin{array}{r}3 \\
7 \\
11 \\
8\end{array}$ & $\begin{array}{l}2 \\
7 \\
2 \\
7\end{array}$ & \\
\hline $\begin{array}{l}344 / 67 \\
211 / 68 \\
245 / 68 \\
243 / 67\end{array}$ & $\begin{array}{l}\text { 47,XY,mar }+ \\
46, X, \operatorname{inv}(Y p+q-) \\
46, X, \operatorname{inv}(Y p+q-) \\
45, X Y, D-, D-, t(D q D q)+\end{array}$ & $\begin{array}{l}24 \\
14 \\
14 \\
26\end{array}$ & $\begin{array}{l}22 \\
19 \\
25 \\
18\end{array}$ & $\begin{array}{l}26 \\
21 \\
27 \\
21\end{array}$ & $\begin{array}{l}3 \\
6 \\
9 \\
5\end{array}$ & $\begin{array}{l}1 \\
1 \\
4 \\
5\end{array}$ & \\
\hline $204 / 67$ & $45, X Y, D-, G-, t(D q G q)+$ & 31 & 20 & 32 & 6 & 2 & \\
\hline $\begin{array}{r}210 / 68 \\
82 / 66 \\
157 / 68 \\
352 / 67 \\
77 / 66\end{array}$ & $\begin{array}{l}\text { 46,XY,t(Bp + ;Eq-) } \\
\text { 46,XY,t(1?+;Cq-) } \\
\text { 46,XY,t(F?+;Gq-) } \\
\text { 46,XY,t(1 }+; 16 \mathrm{p}+) \\
\text { 46,XY,inv }(\mathrm{Cp}-\mathrm{q}+)\end{array}$ & $\begin{array}{l}10 \\
16 \\
16 \\
32 \\
21\end{array}$ & $\begin{array}{l}28 \\
25 \\
21 \\
26 \\
27\end{array}$ & $\begin{array}{l}30 \\
36 \\
24 \\
31 \\
20\end{array}$ & $\begin{array}{l}7 \\
9 \\
7 \\
3 \\
8\end{array}$ & $\begin{array}{l}6 \\
1 \\
2 \\
1 \\
3\end{array}$ & \\
\hline
\end{tabular}


TABLE b

MEASUREMENTS OF PATIENTS WITH SEX CHROMOSOME ABNORMALITIES

\begin{tabular}{|c|c|c|c|c|c|c|}
\hline $\begin{array}{l}\text { Case } \\
\text { No. }\end{array}$ & $\begin{array}{l}\text { Chromosome } \\
\text { Constitution }\end{array}$ & $\begin{array}{l}\text { Age } \\
\text { (yr.) }\end{array}$ & $\begin{array}{c}\text { Height } \\
\text { (cm.) }\end{array}$ & $\begin{array}{c}\text { Arm Span } \\
(\mathrm{cm} .)\end{array}$ & $\begin{array}{l}\text { Pubis to } \\
\text { Sole (cm.) }\end{array}$ & $\begin{array}{c}\text { Weight } \\
\text { (kg.) }\end{array}$ \\
\hline $\begin{array}{r}132 / 68 \\
209 / 68 \\
120 / 68 \\
156 / 68 \\
341 / 67 \\
76 / 66 \\
342 / 67 \\
229 / 68 \\
228 / 68 \\
102 / 66 \\
86 / 66 \\
343 / 67 \\
358 / 67 \\
102 / 68 \\
16 / 67\end{array}$ & $\begin{array}{l}\text { 47,XYY } \\
47, X Y Y \\
47, X Y Y \\
47, X Y Y \\
47, X Y Y \\
47, X Y Y \\
47, X Y Y \\
47, X X Y \\
47, X X Y \\
47, X X Y \\
47, X X Y \\
47, X X Y \\
47, X X Y \\
46, X Y / 47, X X Y \\
46, X X\end{array}$ & $\begin{array}{r}9 \\
14 \\
15 \\
16 \\
17 \\
17 \\
38 \\
13 \\
14 \\
17 \\
17 \\
35 \\
44 \\
16 \\
20\end{array}$ & $\begin{array}{l}132 \\
168 \\
170 \\
171 \cdot 5 \\
199 \\
169 \\
148 \\
160 \\
174 \\
174 \\
158 \\
185 \\
174 \\
173 \\
171\end{array}$ & $\begin{array}{c}128 \\
168 \\
174 \\
173 \\
195 \cdot 5 \\
178 \\
\text { data } \\
142 \\
161 \\
165 \\
158 \\
185 \\
185 \\
170 \\
176\end{array}$ & $\begin{array}{c}\overline{89} \\
86 \\
85 \cdot 5 \\
101 \cdot 5 \\
89 \\
79 \\
84 \\
98 \\
84 \\
99 \\
93 \\
75 \\
86\end{array}$ & $\begin{array}{l}30 \cdot 8 \\
5 \overline{53 \cdot 1} \\
63 \cdot 5 \\
73 \\
62 \cdot 7 \\
36 \cdot 7 \\
48 \cdot 5 \\
63 \cdot 6 \\
55 \cdot 9 \\
66 \cdot 7 \\
81 \cdot 6 \\
54 \cdot 0 \\
65 \cdot 4\end{array}$ \\
\hline
\end{tabular}

TABLE c

CYTOGENETIC DATA ON INDIVIDUALS WITH ABNORMAL CHROMOSOME CONSTITUTION

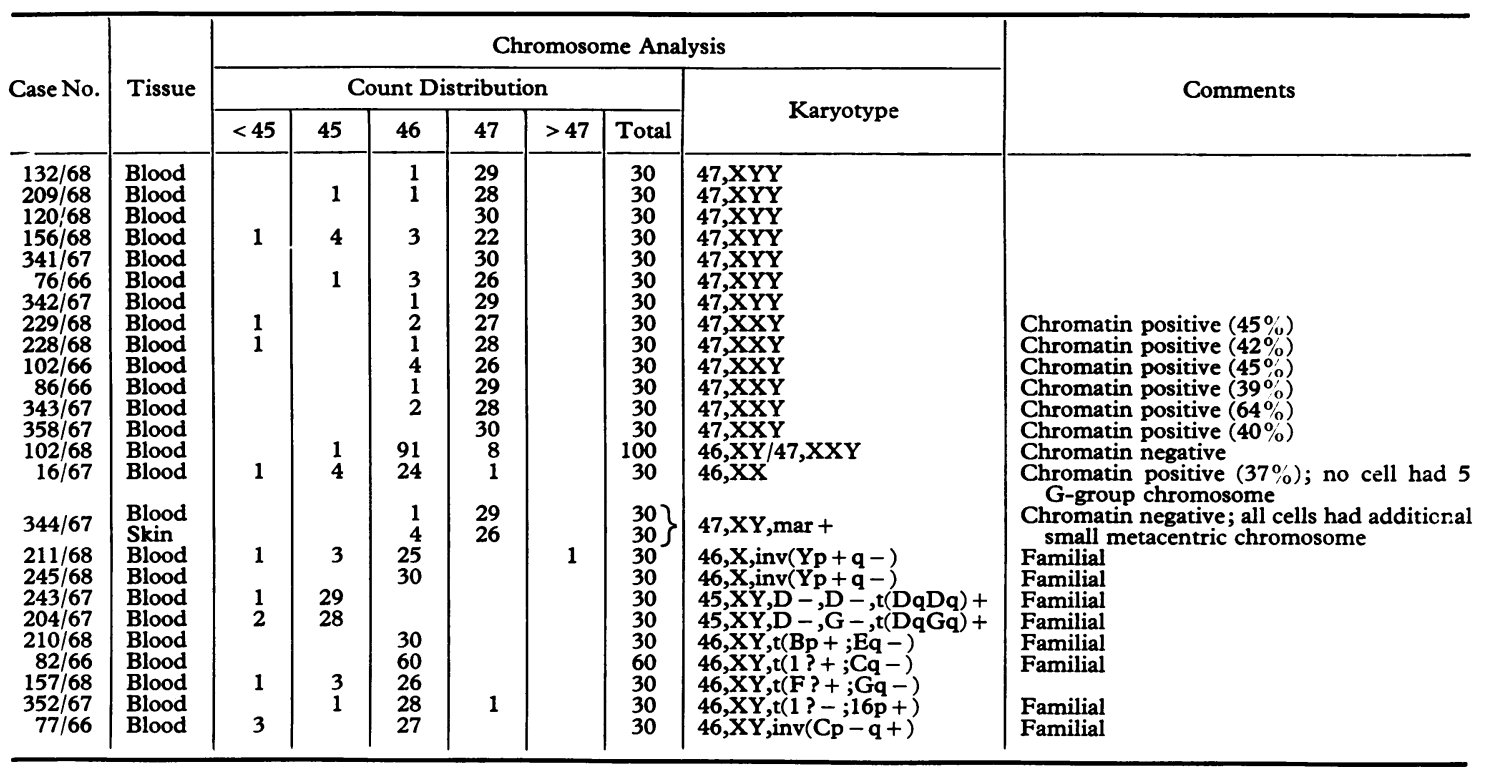

